О. В. Павленко ${ }^{1}$, Т. М. Волосовець ${ }^{1}$, О. М. Дорошенко ${ }^{1}$, М. В. Дорошенко ${ }^{1}$, Н. М. Юнакова ${ }^{1}$, Н. О. Бакшутова ${ }^{1}$, І. Г. Дікова ${ }^{2}$

${ }^{1}$ Національний університет охорони здоров'я України імені П. Л. Шупика, Київ

${ }^{2}$ Національний медичний університет імені О. О. Богомольця, Київ

\title{
ВЕБІНАР ЯК СУЧАСНА ОСВІТНЯ ТЕХНОЛОГІЯ У ПРАКТИЦІ ПІСЛЯДИПЛОМНОЇ МЕДИЧНОЇ ОСВІТИ ЛІКАРІВ-СТОМАТОЛОГІВ
}

\author{
O. V. Pavlenko' ${ }^{1}$, T. M. Volosovets ${ }^{1}$, O. M. Doroshenko ${ }^{1}$, M. V. Doroshenko ${ }^{1}$, \\ N. M. Yunakova', N. O. Bakshutova', I. G. Dikova² \\ ${ }^{1}$ Shupyk National Healthcare University of Ukraine, Kyiv \\ ${ }^{2} O$. Bohomolets National Medical University, Kyiv
}

\section{WEBINAR AS A MODERN EDUCATIONAL TECHNOLOGY IN THE PRACTICE OF POSTGRADUATE MEDICAL EDUCATION OF DENTISTS}

\begin{abstract}
Анотація. Розвиток дистанційної медичної освіти у практиці післядипломної підготовки лікарів-стоматологів з урахуванням пандемії коронавірусної інфекції, що триває більше року, обумовлює зміни у методиках викладання у медичній освіті та необхідність впровадження у післядипломній підготовці лікарів-стоматологів сучасних ефективних освітніх технологій, як-от вебінар.

Мета статті - впровадження сучасної технології проведення вебінарів з актуальних питань стоматологічної практики у післядипломну підготовку лікарів-стоматологів у закладах вищої медичної освіти.

Для поліпшення ефективності підготовки лікарів-стоматологів на кафедрах стоматології Національного університету охорони здоров’я України імені П. Л. Шупика використовується така сучасна навчальна технологія, як вебінар, що стала дієвою складовою частиною освітнього процесу. При цьому реалізується низка важливих завдань щодо навчального процесу, а саме: оволодіння слухачами навичками активності, самостійності у прийнятті рішень, стимуляції до взаємного обміну знаннями та навичками, що безперечно має низку переваг над засвоєнням навчального матеріалу під час директивної трансляції знань від викладача до слухачів.

Вебінари як сучасну ефективну освітню технологію необхідно широко впроваджувати у післядипломну стоматологічну освіту в закладах вищої медичної освіти із використанням наявних WEB-ресурсів.
\end{abstract}

Ключові слова: вебінар; стоматологія; дистанційна освіта.

Abstract. Pandemic of coronavirus infection, which lasts more than a year has led to changes in teaching methods in medical education. The implementation of distant medical education in postgraduate training of dentists was connected with usage of such modern effective educational technologies is webinar.

The aim of the work - introduction of modern such modern educational technology as webinars in postgraduate training of dentists.

In order to improve the efficiency of training of dentists at the departments of dentistry of the P. Shupyk National Healthcare University of Ukraine, we have decided to use modern educational technology - a webinar. It hat become an effective part of the educational process. With its help we have solved a lot of important tasks related to the educational process: encouraging activity, independence in decision-making, stimulating mutual exchange of knowledge and skills, which undoubtedly has a number of advantages over learning material during directive translation of knowledge from teacher to students.

Webinars as a modern effective educational technology should be widely implemented in postgraduate dental education using existing WEB-resources.

Key words: webinar; dentistry; distance education.

Вступ. Розвиток дистанційної медичної освіти у практиці післядипломної підготовки лікарів-стоматологів з урахуванням пандемії коронавірусної інфекції, що триває більше року, обумовлює зміни у медичній освіті та необхідність впровадження у післядипломній підготовці лікарів-стоматологів

() О. В. Павленко, Т. М. Волосовець, О. М. Дорошенко та ін. сучасних ефективних освітніх технологій, до яких відноситься і вебінар [1-3].

Н. В. Морзе та співавт. (2014) вважають, що: «Вебінар (від англ. Web + seminar, webinar) - це технологія, яка забезпечує проведення інтерактивних навчальних заходів у синхронному режимі і надає інструменти для дистанційної спільної роботи 
учасників» [3]. По суті вебінар - це семінар, що проводиться викладачем в інтерактивному режимі.

Як форма синхронного спілкування, найбільш актуальними вебінари є для дистанційного навчання і підвищення кваліфікації.

Для проведення вебінарів у медичній освіті нині використовуються сучасні інформаційно-комунікативні технології, а саме відеоінтернет-конференції на платформах ZOOM, YouTube, Google Meet тощо.

Мета статті - впровадження сучасної технології проведення вебінарів 3 актуальних питань стоматологічної практики у післядипломну підготовку лікарів-стоматологів у закладах вищої медичної освіти.

Теоретична частина. Для поліпшення ефективності підготовки лікарів-стоматологів на кафедрах стоматології Національного університету охорони здоров'я України імені П. Л. Шупика використовується така сучасна навчальна технологія, як вебінар, що стала дієвою складовою частиною освітнього процесу. При цьому реалізується низка важливих завдань щодо навчального процесу, а саме: оволодіння слухачами навичками активності, самостійності у прийнятті рішень, стимуляції до взаємного обміну знаннями та навичками, що безперечно має низку переваг над засвоєнням навчального матеріалу під час директивної трансляції знань від викладача до слухачів.

Безперечною перевагою вебінару у нашій практиці є синхронне спілкування з учасниками у режимі реального часу, що передбачає інтерактивний зв’язок між учасниками навчального процесу, можливість висловлення особистої думки. Інноваційні вебінар-орієнтовані платформи забезпечують зазначене різними методами: через онлайн-опитування учасників (безпосередньо або в чаті), візуалізацію обговорення через представлення викладачем конкретних кейсів, можливість конспектування і надавати запитання ведучому, обмін текстовими файлами і зображеннями, функцію синхронного запису вебінару і поширення його змісту у мережі.

Під час вебінару викладач повинен обов'язково мотивувати слухачів до активного самостійного процесу оволодіння матеріалом та власного пошуку щодо засвоєння нових знань та вмінь у галузі сучасної стоматології. У рамках вебінару слухачам надається навчальний матеріал по темі, відповіді на запитання, що виникають у слухачів під час проведення інтерактивного заняття, можливість обговорення тематичних клінічних випадків.
Вебінар також дає можливість на вхідному рівні оцінити рівень вже набутих знань та вмінь слухачів за запропонованою темою. Крім того, така методика викладання матеріалу вчить лікарів роботи в команді, шляхом обміну надбаною інформацією у процесі заняття. Викладач має спрямовувати вектор можливих дій слухачів відносно особливостей конкретного стоматологічного кейсу. Клінічний розбір окремих ситуаційних завдань має супроводжуватися широкою дискусією із вислуховуванням думок усіх учасників цього процесу, що стимулює розвиток у слухачів елементів клінічного мислення.

Оптимальна тривалість медичного вебінару із розбором клінічного випадку - 1-1,5 год. Структура вебінару включає: аналіз і розбір клінічної ситуації у вигляді вступної презентації щодо моделювання ситуації, практично-орієнтоване подання інформації щодо принципів інтерактивного спілкування, групове обговорення та визначення методів лікування, за необхідності виконання індивідуальних медичних маніпуляцій. Лекційна складова викладача у вебінарі має бути мінімальною до обсягу заняття і слугувати мотиваційним введенням для слухачів у тему заняття.

Важливою складовою вебінару є, на нашу думку, обговорення конкретних дій слухачів при вирішенні клінічної ситуації, що не допускає ознак будьякої пасивності від учасників. По закінченні вебінару слухачі набувають відповідних знань, умінь і компетенцій, напрацьовують конкретні алгоритми надання стоматологічної допомоги. Саме тому при оцінці результативності вебінару необхідно визначити та враховувати конкретний внесок кожного із слухачів.

Для ознайомлення з нашим досвідом ми наводимо нижче приклад вебінару щодо діагностики та лікування різних варіантів виразково-некротичного стоматиту, що може бути використаний як на додипломному, так і післядипломному етапах підготовки лікаря-стоматолога.

План навчального вебінару на тему «Виразковонекротичний стоматит»

Ведучий: викладач кафедри стоматології закладу вищої медичної освіти.

Актуальність. Серед захворювань слизової оболонки порожнини рота виразково-некротичні ураження зустрічаються досить часто, особливо в осіб молодого віку. Вони мають найбільш тяжкий перебіг і можуть призвести до серйозних ускладнень в організмі і тимчасової непрацездатності. 
Це зумовлює необхідність ознайомлення слухачів та поглибленого вивчення цього патологічного стану задля своєчасної діагностики, лікування та профілактики.

Оснащення: комп’ютер, підключений до мережі «Інтернет». Необхідне програмне забезпечення ZOOM, MyOwnConference, Google Meet тощо.

Вибір форми обумовлений необхідністю забезпечення навчального процесу у післядипломній підготовці лікарів за спеціальністю «Стоматологія» в умовах дистанційної форми навчання.

Форма: поєднання лекції із зворотним зв'язком разом з практичним заняттям із вирішенням завдань.

Для кого спрямований: лікарів-інтернів за спеціальністю «Стоматологія» або слухачів курсів післядипломного навчання кафедр стоматології.

Мета - підвищити компетенцію суб'єктів навчання щодо діагностики та тактики лікування виразково-некротичного стоматиту.

Перед вебінаром. За 1,5 тижня до початку вебінару в Інтернеті бажано розмістити інформацію: найменування вебінару, зміст, дату та час проведення. Ця інформація надсилається слухачам на електронні адреси. Необхідно одразу інформувати майбутнього слухача про його успішну реєстрацію. Надіслати лист - нагадування про вебінар у його переддень. Підготовка листа опитування слухачів за темою вебінару.

Підготовка інформаційного листа з настановами для слухачів вебінару:

- за 5-10 хв до початку реєструватися у вебінарі;

- вказувати своє ім'я згідно з паспортом;

- привітати лектора та слухачів вебінару;

- уникати конфліктів;

- використовувати чат тільки для прослуховування вебінару;

- вміти користуватися чатом та мікрофоном.

Для слухачів вебінар відкривається для доступу за 10 хв, тому підготовка до вебінару повинна бути завершена не пізніше ніж за 30 хв до його початку. На початку вебінару інформувати слухачів про порядок, згідно з яким ставляться питання: підняти руку та поставити питання по мікрофону; написати питання в чаті.

Зміст/план вебінару:

1. Вступ та вхідне опитування слухачів.

2. Особливості етіології і патогенезу виразковонекротичного стоматиту та його сучасного перебігу (коротка вступна лекція з презентацією Power Point).
3. Ознайомлення слухачів із сучасними протоколами діагностики та лікування виразково-некротичного стоматиту, зокрема у хворих на COVID-19.

4. Рекомендації та практичні поради слухачам щодо обстеження, лікування хворих на виразковонекротичний гінгівіт та його профілактики (інтерактивна лекція з презентацією Power Point).

5. Розгляд клінічних кейсів щодо виразковонекротичного стоматиту. Яка тактика лікаря-стоматолога? Як оцінити ступінь ураження слизової оболонки порожнини рота? Обгрунтування схеми обстеження та лікування. Показання та протипоказання щодо антибіотикотерапії (практичне заняття).

6. Відповіді на запитання та дискусія з учасниками вебінару (круглий стіл).

7. Опитування слухачів та їх оцінювання.

Графік вебінару: онлайн-лекції зі зворотним зв'язком - 30 хв, практичне заняття з вирішенням завдань - 30 хв.

Вид освітнього процесу: участь у навчальному вебінарі шостого рівня таксономії Блума (оцінювання).

Форма освіти або підвищення кваліфікації: дистанційна.

Вартість надання освітньої послуги: участь безкоштовна.

Напрямок - розвиток професійних компетентностей лікаря-стоматолога щодо діагностики, лікування та профілактики виразково-некротичного стоматиту.

Набуті компетентності:

- особливості діагностики виразково-некротичного стоматиту;

- принципи лікування виразково-некротичного стоматиту;

- профілактика виразково-некротичного стоматиту.

Тривалість вебінару: 1,0 год - кредит ЄКТС: 0.033.

Після закінчення вебінару викладач направляє всім його учасникам електронні листи із копіями посилань на джерела, що використовувалися під час презентації, та подякою за активну участь у вебінарі.

Висновки. Вебінари як сучасну ефективну освітню технологію необхідно широко впроваджувати у післядипломну стоматологічну освіту в закладах вищої медичної освіти із використанням наявних WEB-ресурсів. 


\section{Список літератури}

1. Застосування дистанційної освіти у післядипломній підготовці лікарів-стоматологів в умовах карантинних заходів / О. В. Павленко, Т. М. Волосовець, О. М. Дорошенко [та ін.] // Медична освіта. - № 3. - С. 13-16.

2. Морзе Н. В. Вебінари як засіб підвищення кваліфікації викладачів / Н. В. Морзе, А. Б. Кочарян, Л. О. Вар-

\section{References}

1. Pavlenko, O.V., Volosovets, T.M., Doroshenko, O.M., Doroshenko, M.V., \& Bakshutova, N.O. (2020). Zastosuvannya dystantsiynoyi osvity u pislyadyplomniy pidhotovtsi likariv-stomatolohiv v umovakh karantynnykh zakhodiv [Application of distance education in postgraduate training of dentists in quarantine measures]. Medychna osvita - Medical Education, 3, 13-16 [in Ukrainian].

2. Morse, N.V., Kocharyan, A.B., \& Varchenko-Trotsenko, L.O. (2014). Vebinary yak zasib pidvyshchennya
ченко-Троценко // Інформаційні технології і засоби навчання. - 2014. - Т. 42, вип. 4. - С. 118-130.

3. Community and connectedness in online higher education: a scoping review of the literature / Jesús Trespalacios, Chareen Snelson, Patrick R. Lowenthal [et al.] // Distance Education. - 2021. - Vol. 42, Issue 1. P. 5-21. https://doi.org/10.1080/01587919.2020.1869524.

kvalifikatsiyi vykladachiv [Webinars as a means of teacher training]. Informatsiyni tekhnolohiyi i zasoby navchannyaInformation Technologies and Teaching Aids, 42(4), 118130 [in Ukrainian].

3. Trespalacios, J., Snelson, Ch., Lowenthal, Patrick R., Uribe-Flórez, L., \& Perkins, R. (2021). Community and connectedness in online higher education: a scoping review of the literature. Distance Education 42(1), 5-21. https://doi. org/10.1080/01587919.2020.1869524. 